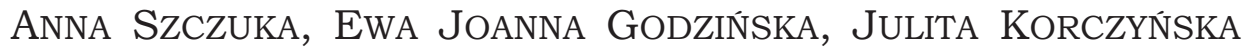 \\ Laboratory of Ethology \\ Nencki Institute of Experimental Biology PAS \\ Pasteur Str. 3, 02-093 Warsaw \\ E-mail: e.godzinska@nencki.edu.pl
}

\title{
FACTORS MEDIATING ANT SOCIAL BEHAVIOR: INTERPLAY OF NEUROMODULATION AND SOCIAL CONTEXT
}

\section{INTRODUCTION}

\section{SOCIAL INSECTS AS MODEL ORGANISMS IN COMPARATIVE RESEARCH ON BIOLOGICAL ROOTS OF SOCIAL BEHAVIOR}

Invertebrates are often used as models in biological research, and in particular in studies devoted to complex interrelationships between functioning of the nervous system, individual behavior and signals arriving from the social level of organization (GODZIŃSKA 1997, 2006; GALIZIA et al. 2012; WNUK 2008, 2013). Social insects are particularly convenient as model organisms for the research devoted to the effects of social environment and social interactions on individual behavior. Social behavior of many insects and, in particular, social $\mathrm{Hy}$ menoptera (wasps, bees and ants) is rich and advanced and its causal factors are complex and mutually interrelated (WILSON 1971; HÖLLDOBLER and WILSON 1990, 2009; GODZIŃSKA 1996, 1997, 2006, 2007, 2016; MAZURKIEWICZ et al. 2015; LEONHARDT et al. 2016; see also GODZIŃSKA et al. 2019, this issue of KOSMOS).

\section{ORGANIZATION OF INSECT SOCIETIES AND SOCIAL COHESION}

Organization of an insect society is not a fixed, rigid structure, but a dynamic process involving constant modifications of the complicated network of social interactions in which the behavior of each individual is constantly adjusted to its changing environ- ment in response to a wide range of external stimuli including, in particular, signals and cues provided by other individuals (WILSON and HÖLLDOBLER 1988; GORDON 1996; HÖLLDOBLER and WILSON 2009; BUBAK et al. 2016; LEONHARDT et al. 2016). The behavior of each individual is thus mediated not only by internal factors, but also by environmental ones, including, in particular, factors related to the so called social context (social environment of the individual defined largely by the properties of colony/social group in which it lives) (LENOIR 1987; SzCZUKA 1996; ROBINSON et al. 1997; GODZIŃSKA 2006, 2019; WNUK and GODZIŃSKA 2006; MAZURKIEWICZ et al. 2015; LEONHARDT et al. 2016). Insect societies also strive to maintain the so called social cohesion allowing them to act as more or less well defined units capable of solving complex problems (for instance, the decision to engage in aggressive conflicts with neighbors; BUBAK et al. 2016). Social cohesion is based mostly on the phenomenon of nestmate recognition, i.e. the ability to discriminate between nestmates (members of the same social group) and non-nestmates (alien individuals) (GoDZIŃSKA 2006; WNUK and GODZIŃSKA 2006; MAZURKIEWICZ et al. 2015; LEONHARDT et al. 2016). Maintenance of social cohesion is attained thanks to the so called affiliative behavior of social group members, i. e. friendly social interactions involving responses to various social cues and communication signals (POOLE 1985; LEONHARDT et al. 2016). Two most important categories of affiliative social contacts involved in the maintenance of

Keywords: ants, neuromodulation, social behavior, social context, social insects

Acknowledgements: This work was supported by the Statutable Grant 407 of the Ministry of Science and Higher Education for the Nencki Institute of Experimental Biology of the Polish Academy of Sciences in Warsaw, Poland. 
social cohesion in social Hymenoptera are called trophallaxis and allogrooming (CYBULSKA and GODZIŃSKA 1999; DAHBI et al. 1999; LENOIR et al. 2001a, 2001b; GODZIŃSKA 2006; WNUK and GODZIŃSKA 2006; MAZURKIEWICZ et al. 2015; LEONHARDT et al. 2016). Trophallaxis most often consists of a mutual contact of mouthparts of two interacting individuals allowing them to exchange alimentary liquid food and/or various active compounds, including, in particular, cuticular hydrocarbons, chemical cues playing a crucial role in the nestmate recognition (HÖLLDOBLER and WILSON 1990, 2009; CYBULSKA and GODZIŃSKA 1999; DAHBI et al. 1999; GODZIŃSKA 2006; MAZURKIEWICZ et al. 2015; see also GODZIŃSKA et al. 2019, this issue of KOSMOS). Cuticular hydrocarbons are synthesized by each individual and then exchanged between nestmates during trophallaxis and various other social contacts, in particular allogrooming (licking other individuals). Continuous exchange of cuticular hydrocarbons leads to formation of a uniform mixture deposited on the body surface of each individual during self-grooming. That colony-specific profile of cuticular hydrocarbons makes possible the discrimination between nestmates and non-nestmates. However, its exact composition is dynamic and needs constant updating (SOROKER et al. 1994; NIELSEN et al. 1999; BOULAY et al. 2000a, 2000b, 2004; LENOIR et al. 2001a, 2001b; HOWARD and BLOMQUIST 2005; GODZIŃSKA 2006; WNUK and GODZIŃSKA 2006; MAZURKIEWICZ et al. 2015; LEONHARDT et al. 2016; see also GoDZIŃSKA et al. 2019, this issue of KOSMOS). Cuticular hydrocarbon profiles of social insects also provide information about many other traits of their bearers, including their reproductive status and behavioral specialization (SLEDGE et al. 2001; WAGNER et al. 2001; LEONHARDT et al. 2016).

\section{BEHAVIORAL ONTOGENY OF SOCIAL INSECT WORKERS}

\section{PHENOTYPIC PLASTICITY ASSOCIATED WITH WORKER DEVELOPMENTAL MATURATION}

In social Hymenoptera (ants and social wasps and bees) worker behavioral development depends to a large degree on worker age (FOREL 1874; OTTO 1958; DOBRZAŃSKA 1959; WILSON 1971; HÖLLDOBLER and WILSON 1990; GODZIŃSKA 2006, 2019; WNUK 2013; MAZURKIEWICZ et al. 2015). However, behavior of each worker is not linked strictly to its chronological age, but rather to the degree of its physiological maturation, and depends also on previous experience of each individual and on its past and present physical and social context (DoBRZAŃSKA 1959; LENOIR 1987; ROBINSON et al. 1997; FÉNÉRON et al. 1996; GORDON 1996; GODZIŃSKA 2006, 2019; WNUK and GODZIŃSKA 2006; MERSCH et al. 2013; WNUK 2013; MAZURKIEWICZ et al. 2015). In social insects belonging to the order Hymenoptera young adult workers as a rule engage first in inside-nest (intranidal) tasks and act mostly as nurses of developing brood and/or the queen(s). As they age, nurses usually switch to outside-nest (extranidal) tasks and from then on they are often denoted as foragers, although extranidal activities include not only foraging, but also other tasks such as nest and/or territory defense and exploration of unknown areas (FOREL 1874; OTTO 1958; DOBRZAŃSKA 1959; LENOIR 1987; WILSON 1971; HÖLLDOBLER and WILSON 1990, 2009; WNUK 2013; MAZURKIEWICZ et al. 2015; see also GoDZIŃSKA et al. 2019, this issue of KOSMOS). The transition from intranidal to extranidal activities is associated with profound changes of worker phenotype and involves modifications of not only behavior, but also many other phenotype traits, including morphological properties of many organs (in particular ovaries, various exocrine glands and specific neuroanatomical structures), contents of various neurotransmitters in the whole brain and in specific brain structures, hemolymph titres of various hormones, body lipid reserves, and contents of specific proteins in the whole-body protein profile (LENOIR 1987; FÉNÉRON et al. 1996; PAGE et al. 2006; GODZIŃSKA 2006; PAGE and AMDAM 2007; ROBINSON 2009; AMDAM 2011; WNUK 2013). That massive system of phenotype changes arises as a consequence of modifications of the expression of thousands of genes (WHITFIELD et al. 2003; HERB et al. 2012; MAZURKIEWICZ et al. 2015; GODZIŃSKA 2019). Switching from relatively safe intranidal tasks to more risky extranidal activities is also accelerated in response to shortened life expectancy (MORON et al. 2008; WOYCIECHOWSKI and MORON 2009; WNUK 2013; MAZURKIEWICZ et al. 2015).

\section{BEHAVIORAL REVERSION}

Most interestingly, worker behavioral development may also be accelerated, retarded and even reversed in response to specific modifications of social context (RösCH 1930; ROBINSON 1992; RoBINSON et al. 1992, 1997; GODZIŃSKA 2006, 2019; WNUK and GODZIŃSKA 2006; MÜNCH et al. 2008; AMDAM 2011; WNUK 2013; MAZURKIEWICZ et al. 2015; see also GoDZIŃSKA et al. 2019, this issue of KOSMOS). The process of reversal of worker behavioral development is known 
as behavioral reversion. In social Hymenoptera behavioral reversion may be induced by exposure of foragers to brood in absence of younger workers acting as nurses. A part of foragers may then return again to intranidal brood care and become the so called reverted nurses. As a consequence of that process almost all phenotype traits that had been modified during the transition from intranidal to extranidal tasks return back to the state characteristic for intranidal workers (RöscH 1930; RoBINSON 1992; ROBINSON et al. 1992, 1997; GODZIŃSKA 2006, 2019; WNUK and GODZIŃSKA 2006; MÜNCH et al. 2008; AMDAM 2011; HERB et al. 2012; WNUK 2013; MAZURKIEWICZ et al. 2015; DUSSUTOUR et al. 2016; see also GODZIŃSKA et al. 2019, this issue of KOSMOS). Importantly, these findings may be interpreted not only in terms of reverted behavioral ontogeny, but also in terms of reverted senescence. According to such an interpretation, ageing processes may not be only delayed or halted, but also reversed, and reversal of senescence may be achieved solely by manipulations of the social context, without any additional pharmaceutical interventions. The research devoted to the role of social context in the mediation of phenotypic plasticity in social insects has thus important implications not only for behavioral and social sciences, but also for experimental gerontology (MÜNCH et al. 2008; AMDAM 2011; MAZURKIEWICZ et al. 2015; GODZIŃSKA 2019).

Interestingly, many experimental findings also suggest that honeybee and ant behavioral reversion show qualitative differences (LENOIR 1979; SORENSEN et al. 1984; WNUK 2013). Phenotype modifications accompanying honeybee behavioral reversion develop in a relatively slow and gradual way (RÖSCH 1930; ROBINSON et al. 1992; HUANG and RoBINSON 1996), but in ants induction of intranidal brood care may occur very rapidly, within $24 \mathrm{~h}$, which argues against exocrine control of that process (LENOIR 1979; SORENSEN et al. 1984; MCDONALD and TOPOFF 1985; WNUK et al. 2011; WNUK 2013; KORCZYŃSKA et al. 2014; SYMONOWICZ et al. 2015). Furthermore, reduction of body lipid stores accompanying the transition from intranidal to extranidal activities is irreversible in honeybees (TOTH and ROBINSON 2005), but reversible in ants (Lasius niger, DUSSUTOUR et al. 2016). Moreover, whereas honeybee foragers may develop phenotype modifications characteristic for behavioral reversion even in absence of developing brood in response to deprivation from contacts with younger workers acting as nurses (HUANG and ROBINSON 1996), in the experiment of KORCZYŃSKA et al. (2014) foragers of the red wood ant Formica polyctena did not respond to deprivation from contacts with younger workers by induction of behavior patterns characteristic for nurses. Analysis of modifications of neurochemical properties of the whole brains and of specific brain structures also revealed further profound differences between honeybee and ant behavioral reversion (see later in this paper).

\section{INTERPLAY OF AGE AND CASTE POLYETHISM}

Division of labor based on behavioral differences related to worker age and/or degree of physiological maturation is usually denoted as age polyethism or temporal polyethism and is widespread in colonies of social Hymenoptera (FOREL 1874; OTTO 1958; DOBRZAŃSKA 1959; LENOIR 1987; WILSON 1971; HÖLLDOBLER and WILSON 1990, 2009; WNUK 2013; MAZURKIEWICZ et al. 2015). However, some ant species are polymorphic and their colonies contain workers differing with respect to body size and/ or proportions of various body parts: small minor workers (minors), large major workers (majors) possessing disproportionately large heads, and sometimes also intermediate forms, media workers (WILSON 1971; HöLLDOBLER and WILSON 1990; WNUK 2013; MAZURKIEWICZ et al. 2015; see also GODZIŃSKA et al. 2019, this issue of KOSMOS). Workers of polymorphic ants differ not only with respect to morphology, but also with respect to behavioral repertoires (the phenomenon of caste polyethism). Caste polyethism and age (temporal) polyethism usually co-occur and jointly intervene in the mediation of social insect behavior (WILSON 1971; HÖLLDOBLER and WILSON 1990; MAZURKIEWICZ et al. 2015, 2016). Many studies also documented complex relationships between worker morphology, neuroanatomical and neurochemical properties of the whole brain and/or specific brain structures, effects of administration of various neuroactive compounds, and worker behavior (PUNZO and WILLIAMS 1994; Muscedere and TRANIELlO 2012; GiRALDO et al. 2013; ILIEŞ et al. 2015; KAMHI et al. 2015; MAZURKIEWICZ et al. 2015).

\section{THE ROLE OF NEUROACTIVE COMPOUNDS IN THE MEDIATION OF ANT SOCIAL BEHAVIOR}

\section{OCTOPAMINE: GENERAL REMARKS}

The biogenic amine octopamine (OA), a neuroactive compound widespread in invertebrates and known to act as a neurotransmitter, neuromodulator, and neurohormone, is usually considered to represent a functional equivalent of noradrenaline (ROED- 
ER et al. 2003; ROEDER 2005). Octopamine plays a major role in the mediation of behavior of social Hymenoptera (SCHULZ and ROBINSON 2001; GODZIŃSKA 2006; SCHEINER et al. 2006; GALIZIA et al. 2012; WNUK 2012, 2013; KAMHI and TRANIELlO 2013; MAZURKIEWICZ et al. 2015; MAZURKIEWICZ 2019; see also GoDZIŃsKA et al. 2019, this issue of KOSMOS). In particular, octopamine acts as a key molecule in the control of honeybee behavior (SCHEINER et al. 2006; GALIZIA et al. 2012) and is involved, among others, in the mediation of associative olfactory learning (HAMMER 1993; HAMMER and MENZel 1998; MENZEL and MÜLLER 1996; GIURFA and SANDOZ 2012), nestmate recognition and aggressive behavior (ROBINSON et al. 1999), and behavioral ontogeny and division of labor (HARRIS and WOODRING 1992; SCHULZ and ROBINSON 1999, 2001; SCHULZ et al. 2002a, 2002b, 2003; WAGENER-HULME et al. 1999; GODZIŃSKA 2006; WNUK 2013). Octopamine also participates in the control of specific behavior patterns such as foraging responses to brood pheromone (BARRON and ROBINSON 2005), waggle dances used by foragers to communicate the direction and distance to important resources (BARRON et al. 2007), hygienic behavior (removal of diseased brood; SPIVAK et al. 2003), scouting (seeking new food sources and nest sites; LIANG et al. 2012), and phototaxis (SCHEINER et al. 2014).

In view of key importance of octopamine in the control of behavior and physiology of social insects, we decided to focus our review on that biogenic amine, and to provide only selected examples of the involvement of other biogenic amines (serotonin, dopamine and tyramine) and other neuroactive compounds [classical amino acid neurotransmitters $\gamma$-aminobutyric acid (GABA) and glutamate (Glu)] in the mediation of insect social behavior.

\section{AFFILIATIVE BEHAVIOR AND SOCIAL COHESION}

Important role of octopaminergic system in the mediation of nestmate recognition among social Hymenoptera has already been documented by numerous studies. High brain levels of octopamine and/or administration of octopamine or agonists of octopaminergic receptors were repeatedly found to enhance the discrimination between nestmates and non-nestmates in both honeybees (RoBinson et al. 1999) and ants (VANDER MEER et al. 2008). Interesting results were also brought about by studies devoted to complex interrelationships between brain octopamine levels, effects of octopamine administration, and behavioral effects of vari- ous forms of social deprivation in several species of ants (BOULAY et al. 1999a, 1999b, 2000b; KORCZYŃSKA et al. 2005; WADA-KATSUMATA et al. 2011; see also GoDZIŃSKA et al. 2019, this issue of KOSMOS). Ant workers reunited with nestmates after a period of social isolation show increased propensity to engage in trophallaxis (the so called isolation-induced trophallaxis; BOULAY et al. 1999a, 1999b, 2000a, 2000b, 2003, 2004; DAHBI et al. 1999; CYBULSKA et al. 2000; KATZAV-GOZANSKY et al. 2004; KORCZYŃSKA et al. 2005; WAGNER-ZIEMKA et al. 2008; MAZURKIEWICZ et al. 2015; see also GODZIŃSKA et al. 2019, this issue of KOSMOS). That behavior is accompanied by exchange of cuticular hydrocarbons that allows the ants that had been subjected to social isolation to reintegrate with their nestmates (DAHBI et al. 1999; BOULAY et al. 2000a, 2000b, 2004; LENOIR et al. 2001b; GODZIŃSKA 2006; WNUK and GODZIŃSKA 2006; MAZURKIEWICZ et al. 2015; LEONHARDT et al. 2016). Isolation-induced trophallaxis may, however, be strongly reduced by acute administration of octopamine in form of abdominal injections (Camponotus fellah: Boulay et al. 1999a, 2000b, Camponotus herculeanus: KORCZYŃSKA et al. 2005). Octopamine administration also reduced antennal contacts observed during dyadic encounters between nestmates taking place after a period of social isolation (C. herculeanus: KoRCZYŃsKA et al. 2005) and cuticular hydrocarbon transfer between nestmates (C. fellah: Boulay et al. 2000b). In addition, both octopamine and its metabolic precursor tyramine exerted stimulatory effects on self-grooming, a behavior pattern also involved in the formation and updating of cuticular hydrocarbon profiles crucially involved in the maintenance of social cohesion in ant colonies (KoRCZYŃSKA et al. 2005). However, the effects of octopamine administration on affiliative social interactions taking place during dyadic encounters between ant workers that had been subjected to social isolation were strictly specific for that compound. Administration of three other biogenic amines, serotonin (BOULAY et al. 2000b), dopamine, and tyramine (KORCZYŃSKA et al. 2005) did not exert any significant effect on any aspect of social behavior of the tested ants.

In the light of these findings Boulay et al. (2000b) put forward a hypothesis proposing that social isolation leads to decrease of worker brain octopamine levels and to a concomitant increase of readiness to engage in social contacts, and in particular in trophallaxis. When reduced brain octopamine levels are restored by octopamine administration, isolation-induced trophallaxis 
is partly suppressed. BOULAY et al. (2000b) and KORCZYŃSKA et al. (2005) also pointed out that octopamine is known to play an important role in the mediation of reward processes involved in olfactory conditioning in the honeybees (HAMMER 1993; HAMMER and MENZEL 1998). Therefore, they proposed that octopamine may also be involved in the hypothetical phenomenon of social reward accompanying affiliative interactions between ant nestmates. If so, behavioral effects of administration of exogenous octopamine may mimic the hypothetical octopamine-mediated rewarding effects of trophallactic exchanges (BOULAY et al. 2000b, KORCZYŃSKA et al. 2005, GODZIŃSKA 2006; see also GODZIŃSKA et al. 2019, this issue of KOSMOS).

The phenomenon of social reward accompanying affiliative contacts between social insects remains, however, hypothetical. Moreover, some findings do not support the general hypothetical picture of interrelationships between social isolation, effects of octopamine administration, brain octopamine levels and affiliative social contacts that had been proposed by BOULAY et al. (2000b) and KORCZYŃSKA et al. (2005) (see also GODZIŃSKA et al. 2019, this issue of KOSMOS). Thus, already in the study of KORCZYŃSKA et al. (2005) octopamine was found to exert stimulatory (and not inhibitory) effect on allogrooming, a behavior pattern also involved in the maintenance and updating of colony-specific cuticular hydrocarbon profiles. Subsequently, WADA-KATSUMATA et al. (2011) reported that workers of Formica japonica responded to 2 day social isolation by significant increase (and not decrease) of brain levels of octopamine. However, if social isolation was followed by affiliative interactions with nestmates (trophallaxis and allogrooming), brain octopamine levels of isolated workers decreased and were similar as in the case of non-isolated controls and workers isolated only during $1 \mathrm{~h}$ (see also GODZIŃSKA et al. 2019; this issue of KOSMOS).

SzCZUKA et al. (2013) also found out that trophallactic exchanges between nestmates of $F$. polyctena that had not been subjected to social isolation are not influenced by abdominal injections of octopamine. However, all four biogenic amines tested in that study (octopamine, serotonin, dopamine and tyramine) exerted inhibitory effects on allogrooming observed during dyadic confrontations of the tested workers with their nestmates, and serotonin and tyramine also exerted inhibitory effects on their antennal contacts with nestmates. Serotonin and dopamine also reduced trophallactic contacts taking place during dyadic confrontations of workers of $F$. polyctena with non-nestmate conspecifics. In contrast, KOYAMA et al. (2015) documented again inhibitory effects of octopamine administration on ant affiliative behavior. In their experiment oral octopamine administration reduced affiliative interactions (trophallaxis and allogrooming) between cooperating founding queens of Polyrhachis moesta in spite of the fact that interacting ants had not been subjected to complete social isolation.

BUBAK et al. (2016) investigated complex interrelationships between brain levels of three biogenic amines (octopamine, serotonin and dopamine), social context immediately preceding the measurements of biogenic amine levels, and duration of exposure to specific social context in workers of the pavement ant Tetramorium caespitum. In that study worker brain octopamine levels rose after interactions with live nestmates and after confrontations with ant mimics coated with both nestmate and nonnestmate cuticular hydrocarbons, but remained undmodified after fights with nonnestmates. Interestingly, stronger and more long-lasting effects were observed after contacts with non-nestmate hydrocarbons than after contacts with nestmate hydrocarbons, which suggests that octopamine is involved in nestmate receognition.

Confrontation with live nestmates or with ant mimics coated with nestmate cuticular hydrocarbons was also followed by significant increase of brain levels of serotonin. No such effects were, however, observed as a consequence of confrontations with either non-nestmates, or ant mimics coated with non-nestmate cuticular hydrocarbons. Lastly, dopamine levels in brains of workers of $T$. caespitum significantly increased after confrontations with live conspecifics, both nestmates and non-nestmates, but remained unmodified after confrontations with both types of ant mimics. Stronger and more long-lasting effects were observed after fights of the tested ants with non-nestmates. Worker brain levels of each of the biogenic amines investigated in that study depended thus in a different way on social context preceding their mesurements.

\section{AGGRESSIVE BEHAVIOR}

The use of ants as model organisms in comparative research devoted to neurochemical processes involved in the mediation of aggressive behavior was initiated by KosTOWSKI and his coworkers already more than half a century ago (KosTOWSKI 1966, 1968, 1994; KOSTOWSKI and TARCHALSKA 1972; KOSTOWSKI et al. 1966, 1972, 1975a, 1975b; TARCHALSKA et al. 1975). The main bioassay 
used in that research consisted of a short (3-15 min) confrontation of a group of workers of the red wood ant Formica rufa (10-15 individuals) with an allospecific intruder, a large beetle of the genus Geotrupes. The authors of these studies recorded and analysed aggressive responses directed by the tested ants both to the beetle and to other nestmates also participating in that group attack (KOSTOWSKI 1966, 1968; KOSTOWSKI and TARCHALSKA 1972; KOSTOWSKI et al. 1972, 1975a, 1975b; TARCHALSKA et al. 1975). Research techniques used in these studies also included administration of neuroactive compounds in food (KosTOwSKI 1966, 1968; KoSTOWSKI et al. 1966) or in form of abdominal injections (KostowsKI 1966, 1968; KostowsKI et al. 1966, 1972, 1975a; KosTOWSKI and TARCHALSKA 1972), and measurements of brain levels of specific neurochemicals (KosTOWSKI et al. 1972, 1975a, 1975b; TARCHALSKA et al. 1975). These experiments documented for the first time the involvement of biogenic amines in the mediation of various forms of insect aggressive behavior (KOSTOWSKI and TARCHALSKA 1972; KOSTOWSKI et al. 1972). They also revealed that serotonin and dopamine, two biogenic amines known to participate in the mediation of aggressive behavior of numerous other animals, including vertebrates and in their number also humans, are also critically involved in the control of ant aggressive behavior (KosTOWSKI and TARCHALSKA 1972; KOSTOWSKI et al. 1972, 1975a, 1975b; TARCHALSKA et al. 1975; KOSTOWSKI 1994; MAZURKIEWICZ et al. 2015). However, the relationships between brain levels of serotonin and dopamine, effects of administration of these compounds and various aspects of ant aggressive behavior were rather complex. Thus, workers of $F$. rufa showed similar increase of brain levels of serotonin after a group confrontation with a beetle and with a group of antennalectomized nestmates (KosTOWSKI et al. 1975b; TARCHALSKA et al. 1975). Abdominal injections of serotonin and its metabolic precursor 5-hydroxytryptophan reduced the numbers of the ants attacking the beetle, but increased the numbers of fights between the nestmates participating jointly in that group attack (KOSTOWSKI and TARCHALSKA 1972; KostOWsKI et al. 1972; KosTOWsKI 1994). Abdominal injections of dopamine and drugs increasing brain dopamine levels also exerted strong stimulatory effects on aggressive responses of workers of $F$. rufa to their nestmates, but had no significant effect on their aggressive responses to the beetle or even reduced their level. Abdominal injections of haloperidol (dopamine D2 receptor antagonist) exerted opposite effects: an increase of attacks directed to the beetle and a concomitant decrease of attacks directed to the nestmates (KosTOWSKI et al. 1975a; KosTOWsKI 1994).

Important involvement of dopamine and serotonin in the mediation of ant aggressive behavior was also confirmed by a more recent study, also co-authored by W. KosTOWSKI (SZCZUKA et al. 2013). That study involved a very detailed analysis of the effects of abdominal injections of four biogenic amines (dopamine, serotonin, octopamine and tyramine) on behavior of workers of the red wood ant $F$. polyctena during four types of dyadic aggression tests consisting of a confrontation of a single forager with a nestmate, a non-nestmate conspecific, an allospecific ant (worker of Formica fusca), or a potential insect prey (a small nymph of the house cricket, Acheta domesticus). Significant effects of biogenic amine treatment on ant aggressive behavior were observed only in the case of the confrontations of the tested ants with allospecific opponents. Behavior patterns displayed by the tested ants during dyadic confrontations with workers of $F$. fusca and with small crickets were very similar, but abdominal injections of dopamine and serotonin had different consequences in these two contexts. Dopamine exerted stimulatory effects on threatening behavior directed by workers of $F$. polycte$n a$ to allospecific ants, but stimulated both threatening behavior and physical aggression (biting behavior) during their confrontations with small crickets. In contrast, serotonin enhanced some highly escalated forms of aggressive behavior directed to allospecific ants, dragging of the opponent and formic acid spraying. Neither serotonin, nor dopamine exerted any significant effect on aggressive behavior directed by workers of $F$. polyctena to their conspecifics, both nestmates and non-nestmates. However, administration of these biogenic amines exerted suppressing effect on trophallactic contacts between non-nestmate conspecific ants.

Surprisingly, octopamine administration did not exert any significant effect on any aspect of aggressive behavior of ants tested in any of four contexts investigated in that experiment. However, similarly as dopamine and serotonin, octopamine also reduced affiliative social contacts (trophallaxis) with non-nestmate conspecifics.

Yet another biogenic amine used in the discussed study, tyramine, influenced in an opposite way aggressive behavior directed by workers of $F$. polyctena to two different categories of allospecific opponents, workers of F. fusca and small crickets. Tyramine exerted inhibitory effect on threatening behavior 
directed by the tested ants to workers of $F$. fusca, but stimulated open-mandible threats directed to cricket nymphs (SzCZUKA et al. 2013).

The findings of SzCZUKA et al. (2013) illustrate well how a specific neuroactive compound may exert totally different effects as a function of context in which it was administered. For instance, serotonin exerted suppressing effects on some categories of affiliative social contacts between nestmates (antennal contacts and allogrooming) and non-nestmates (trophallaxis), but during confrontations with allospecifics stimulated escalated aggressive behavior.

Absence of significant effects of octopamine administration on aggressive behavior of workers of $F$. polyctena reported by SzCZUKA et al. (2013) was surprising, as in social Hymenoptera octopamine is well known to be involved in the mediation of various forms of aggressive behavior observed in a wide range of contexts including encounters with nestmates, non-nestmate conspecifics, allospecific ants, and other allospecific insects acting either as predators or as potential prey (RoBINSON et al. 1999; KAITA et al. 2004; OZAKI et al. 2004; SzCZUKA and GODZIŃSKA 2008; VANDER MEER et al. 2008; AONUMA and WATANABE 2012a; KAMHI et al. 2015, 2017; KOYAMA et al. 2015; BUBAK et al. 2016; YAKOVLEV 2018; MAZURKIEWICZ 2019). In particular, octopamine administration was found to reduce not only behavioral effects of complete social deprivation (isolation-induced trophallaxis; Boulay et al. 1999a, 2000b, KORCZYŃSKA et al. 2005), but also behavioral effects of partial social deprivation, namely, modifications of responses to potential insect prey following dramatic reduction of worker group size (SzCZUKA and GODZIŃSKA 2008). As shown by SzCZUKA and GoDZIŃSKA (1997, 2000, 2004a, 2004b), workers of the red wood ant Formica polyctena living in small groups (composed of less than 30 individuals) cease to respond to dead insect prey by complete sequences of predatory/scavenging behavior terminated by prey retrieval to the nest. Their responses to prey are now usually limited to antennal contacts, exploratory nibbling, biting, or at the best abortive transport not terminated by prey retrieval. These behavioral consequences of reduction of group size may be partly counterbalanced by chronic oral administration of octopamine (SzCZUKA and GODZIŃSKA 2008; see also GoDZIŃSKA et al. 2019, this issue of KOSMOS).

Octopamine administration may also influence ant aggressive behavior by counterbalancing behavioral effects of yet another form of social deprivation, queen removal.
Workers of the fire ant Solenopsis invicta were found to respond to queen absence by significant decrease of brain octopamine levels and decreased aggressiveness toward non-nestmates. However, both these effects were restored if queenless ants were fed with carbohydrate food supplemented with octopamine (VANDER MEER et al. 2008). In a similar study YAKOVLEV (2018) investigated the effects of queen presence/absence and oral administration of octopamine on aggressive responses of workers of the red wood ant Formica aquilonia to their natural predators, large predatory beetles Pterostichus magus. Oral octopamine administration exerted stimulatory effect on aggressive responses of the tested ants to beetles, but, surprisingly, their aggressive behavior was not influenced by queen presence/absence (see also GoDZIŃSKA et al. 2019, this issue of KOSMOS).

Involvement of brain octopaminergic system in the mediation of ant predatory behavior was also documented by AONUMA and WATANABE (2012a) who found out that workers of Formica japonica known to engage in predatory behavior had higher brain levels of $\mathrm{N}$-acetylooctopamine than queens that do not engage in hunting. The role of octopaminergic system in the mediation of aggressive behavior was also studied in workers of the Australian weaver ant (Oecophylla smaragdina) (KAMHI et al. 2015). In colonies of these ants smaller minor workers act as nurses, and larger major workers defend territories fighting with conspecific non-nestmates. Majors were found to have higher brain octopamine levels than minors, and frequency of aggressive responses to nonnestmates, a key component of territorial defense, was found to be significantly correlated with worker brain octopamine levels. Moreover, levels of aggression characteristic of each worker size class could be reversed by pharmacological manipulations. Topical (transcuticular) application of octopamine exerted stimulatory effect on aggressive responses to non-nestmates displayed by minors, and oral administration of epinastine, a specific antagonist of octopamine receptors, reduced aggressive responses of majors. No significant relationships were found between any aspect of behavior of the tested ants and brain levels of two other biogenic amines investigated in that study, dopamine and serotonin (KAMHI et al. 2015).

The role of octopamine, serotonin and dopamine in the mediation of aggressive behavior directed by ants to non-nestmates was also investigated by BUBAK et al. (2016) in the pavement ant $T$. caespitum. As already told, interactions with live nestmates 
and contacts with ant mimics coated with nestmate cuticular hydrocarbons were found to elevate levels of serotonin and octopamine in brains of these ants. As it was already known that the decision of workers of $T$. caespitum to engage in fights with nonnestmates is facilitated in by recent interactions with nestmates (HOOVER et al. 2016), these findings suggest that elevation of brain levels of octopamine and serotonin appearing as a consequence of contacts with nestmates and/or nestmate cuticular hydrocarbons is involved in priming of brains of pavement ants for fighting with non-nestmates. This conclusion is also supported by the results of an additional experiment that showed that acute oral administration of octopamine and serotonin exerts a stimulatory effect on responses of these ants to nonnestmates. In contrast, worker brain levels of dopamine were found to increase only after interactions with live ants and, in particular, after fights with non-nestmates. This implies that in workers of that ant species direct physical contacts with other ants, and not only contacts with non-nestmate chemical cues, are necessary to elevate brain dopamine levels.

We should, however, bear in mind that the consequences of octopamine administration on ant aggressive behavior may include not only stimulatory effects, but also absence of significant effects, as in the study of SzcZuKA et al. (2013). Similarly, in the study of KoyAma et al. (2015) octopamine administration was not followed by the increase of mutual aggressiveness between cooperating founding queens of the ant species $P$. moesta, although it contributed to disappearance of cooperation between these queens as a consequence of a suppressing effects exerted on their affiliative interactions. In yet other studies octopamine administration was also found to exert inhibitory effects on ant aggressive behavior, namely, reduce aggressive responses of workers of Camponotus japonicus to non-nestmates (KAITA et al. 2004) and to blends of non-nestmate cuticular hydrocarbons (OzAKI et al. 2004). Interestigly, in the study of OzAKI et al. (2004) octopamine administration elevated aggression threshold of active and aggressive workers, but had no effect on behavior of less active and less aggressive ones.

Numerous striking examples of contextdependence of the effects of administration of octopamine were also recently reported by MAZURKIEWICZ (2019) who investigated the effects of oral chronic administration of octopamine on aggressive behavior of very young (callow) workers of $F$. polyctena. Two behavioral biossays used in that study included the so called head irritation test, during which the experimenter applied aversive mechanical stimulation to the front part of the head of a tethered worker (tested at the age of $1,4,7$ or 10 days posteclosion), and dyadic aggression test, during which a freely moving worker (tested at the age of 12 days posteclosion) was confronted with another allospecific callow worker (Formica rufibarbis). Octopamine treatment exerted both stimulatory and inhibitory effects on various aspects of aggressive behavior of the tested ants in a strongly context-dependent way. The effects of octopamine administration depended on worker age, type of bioassay, and specific behavioral category and/or variable. Stimulatory effects of the administration of octopamine were observed mainly during head irritation tests, and inhibitory ones during dyadic aggression tests.

Similar examples of strong context-dependence of effects of administration of a specific neuroactive compound were also in other social insects. For instance, BEHRENDS and SCHEINER (2012) reported that octopamine injections improved learning performance of very young honeybee workers by increasing their sensitivity for sucrose. However, octopamine treatment did not improve learning performance of mature foragers, although it also increased their sensitivity for sucrose reward.

\section{WORKER BEHAVIORAL ONTOGENY}

Neuromodulation of behavior plays a very important role in behavioral ontogeny of social insect workers and in particular in the mediation of the transition from intranidal to extranidal activities. Interestingly, neurochemical modifications accompanying that transition show important differences between honeybees and ants. Behavioral ontogeny of honeybee workers is mediated above all by octopamine (HARRIS and WOODRING 1992; SCHULZ and ROBINSON 1999, 2001; WAGENER-HULME et al. 1999; ScHULZ et al. 2002a, 2002b, 2003; WNUK 2013). In particular, worker transition from inside-nest to outside-nest tasks is accompanied by the increase of octopamine levels both in the whole brain and in the antennal lobes, brain structure engaged mainly in processing of olfactory stimuli (HARRIS and WOODRING 1992; WAGENER-HULME et al. 1999; SCHULZ and ROBINSON 1999; SCHULZ et al. 2002a). Transition from intranidal to extranidal activities may also be accelerated by oral administration of octopamine (but not tyramine) (SCHULZ and ROBINSON 2001; SCHULZ et al. 2002a). 
In contrast, brain octopamine levels of ant workers do not change during the transition from intranidal to extranidal activities (Pheidole dentata: SEID and TRANIELLO 2005), or even show significant decrease ( $F$. polyctena: WNUK et al. 2011; see also WNUK 2013). In ant workers developmental transition from intranidal to extranidal activities involves mainly the maturation of serotonergic system (SEID and TRANIELLO 2005; SEID et al. 2008; MUSCEDERE et al. 2012; GIRALDO et al. 2013; WNUK 2013). Among others, age-related increase of serotonergic imunoreactivity in the optic lobes of the brains of workers (both majors and minors) of $P$. dentata suggests that serotonin is involved in ontogenetic development of the visual system playing an important role in extranidal tasks (SEID et al. 2008). Developmental maturation of brain serotonergic system was also found to facilitate the induction of trail-following behavior in minor workers of $P$. dentata (MUSCEDERE et al. 2012). In workers of that species onset of foraging was found to be accompanied by synaptic remodeling in olfactory regions of the brain, proliferation of serotonergic neurons, and increased brain contents of serotonin. Experimental depletion of brain serotonin levels by oral administration of the serotonin synthesis inhibitor a-methyltryptophan (AMTP) was followed by reduction of trailfollowing behavior (MUSCEDERE et al. 2012).

Brain dopaminergic system was also found to participate in the mediation of ant foraging behavior. As reported by GIRALDO et al. (2016), extranidal workers of P. dentata had higher brain dopamine levels than intranidal ones. Similary, in a field experiment of FRIEDMAN et al. (2018) pharmacological enhancement of dopamine contents in brains of workers of the harvester ant species Pogonomyrmex barbatus was followed by significant increase of their foraging activity. That study also reported important differences among colonies with respect to biogenic amine contents in brains of foragers. Moreover, colonies that were the most sensitive to humidity proved also to be more responsive to the stimulatory effect of exogenous dopamine administration.

Neurochemical correlates of honeybee and ant behavioral reversion also show fundamental differences. Reverted honeybee nurses and foragers from the reversion colonies were found to differ significantly with respect to biogenic amine levels in the antennal lobes and in the parts of the brain that remained after the removal of the mushroom bodies and the antennal lobes. These differences followed almost exactly the same pattern as differences between con- trol nurses and control foragers: contents of all three biogenic amines investigated in that study (srotonin, dopamine and octopamine) in these two brain structures were always higher in the case of foragers than in the case of nurses regardless of their age. These findings suggest strongly that honeybee behavioural reversion is accompanied by the reversal of modifications of neurochemical properties of these brain structures associated with the transition from intranidal to extranidal tasks, and in particular by the decrease of the octopamine contents in the antennal lobes (ScHULZ and RoBINSON 1999).

Neurochemical correlates of ant behavioral reversion proved, however, to be different (WNUK et al. 2011). Comparison of neurochemical properties of brains of nurses, foragers and reverted nurses of the red wood ant $F$. polyctena showed that brain octopamine levels that decrease during the transition from intranidal to extranidal tasks remain low also in the case of reverted nurses. Brain octopamine levels of workers of $F$. polyctena are thus maturation-related rather than task-related. We may also note that the analysis of serotonin levels in brains of nurses, foragers and reverted nurses of $F$. polyctena discovered two interesting nonsignificant trends: serotonin levels tended to be the highest in brains of foragers, and tended to take intermediate values in the case of reverted nurses in relation to both nurses and foragers. As serotonergic system was reported to play a very important role in the mediation of worker behavioral ontogeny in other ant species (SEID and TRANIELLO 2005; SEID et al. 2008; MUSCEDERE et al. 2012; GIRALDO et al. 2013; WNUK 2013), further research devoted to its possible involvement in behavioral maturation and behavioral reversion in workers of $F$. polyctena may yet yield very interesting findings.

\section{NEUROCHEMICAL CORRELATES OF CHANGES OF THE REPRODUCTIVE STATUS OF THE} INDIVIDUAL

In social insects changes of the reproductive status of the individual may also be accompanied by important phenotype modifications (CUVILLIER-HOT and LENOIR 2006; AONUMA and WATANABE 2012b; LEONHARDT et al. 2016; OHKAWARA and AONUMA 2016). In queenless ants reproductive roles of colony members are determined by inter-individual behavioral interactions: potential reproducers form dominance hierarchies as a consequence of aggressive confrontations. In colonies of queenless ants from the species Streblognathus peetersi belonging to ant subfmily Ponerinae differences in worker status were found to be associated with significant 
differences in brain biogenic amine levels. Dominant (alpha) workers had higher brain octopamine levels than other high-ranking workers and subordinate ones. Surprisingly, brain dopamine levels proved to be significantly higher in subordinate workers than in dominant and other high-ranking workers. Finally, brain serotonin levels of these three classes of workers did not show significant differences.

Modifications of brain biogenic amine levels following changes of reproductive status were also reported in queens of $F$. japonica, a species belonging to the common ant subfamily Formicinae. Wing shedding by the queens that had been fecondated during a mating flight and now were starting a new colony was accompanied by significant decrease of brain levels of serotonin, dopamine and octopamine, and by concomitant increase of brain level of tyramine (AONUMA and WATANABE 2012b). However, this result was not replicated in another study investigating the same question in a different ant species. In queens of the social parasite species Vollenhovia nipponica belonging to another common ant subfamily Myrmicinae wing shedding was associated with the increase (and not decrease) of brain levels of serotonin and dopamine, and concomitant onset of violent aggressive behavior not observed in winged queens (OHKAWARA and AONUMA 2016).

\section{CLASSICAL AMINO ACID NEUROTRANSMITTERS}

Other neuroactive compounds involved in the mediation of physiology and behavior of social insects include classical amino acid neurotransmitters $\gamma$-aminobutyric acid (GABA) and glutamate (Glu) (GALIZIA et al. 2012; WNUK 2012, 2013; WNUK et al. 2014; MAZURKIEWICZ et al. 2015).The role of these compounds in the mediation of behavior of social insects is much better known in the case of honeybees (GALIZIA et al. 2012) than in the case of ants (WNUK 2012, 2013, WNUK et al. 2014). However, some interesting findings concerning the role of these neurotransmitters in the mediation of behavior were reported also in studies investigating various ant species. Thus, PUNZO and WILLIAMS (1994) found out that major workers of the carpenter ant Camponotus floridanus had higher brain GABA levels than minors. However, the Authors of that study did not discuss that result in terms of behavioral differences between these two classes of workers. In a more recent study WNUK et al. (2014; see also WNUK 2013) showed that differences between GABA and Glu levels in brains of ant workers may be related to differences in ecology of the test- ed ant species and to social context (queen presence/absence). Measurements of brain levels of these two neurotransmitters taken after dyadic encounters of the tested ants with three types of opponents (a nestmate, a non-nestmate alien conspecific, or a small nymph of the house cricket) did not reveal any significant effects of the type of the opponent. However, brain GABA levels (in $\mu \mathrm{mol} /$ brain) and GABA/Glu ratio proved to be higher in the case of workers of Myrmica ruginodis (a submissive species) than in the case of workers of $F$. polyctena (a dominant, aggressive red wood ant species) in spite of smaller brain weight of $M$. ruginodis. In the case of $F$. polyctena (but not $M$. ruginodis) brain GABA levels were also significantly higher in workers from queenless colony fragments than in workers from queenright ones. As GABA agonists are known to enhance friendly social behavior in vertebrates (among others ŠUSTKOVÁ-FIŠEROVÁ et al. 2009), it seems probable that elevated brain GABA levels of orphaned workers of $F$. polyctena may facilitate the adoption of a new queen, a phenomenon widespread in orphaned colonies of red wood ants (CZECHOWSKI 1996). All these findings taken together suggest that GABA signalling may be involved in inhibition of ant aggressive behavior. The results of WNUK et al. (2014) also show that not only basic brain levels of amino acid neurotransmitters, but also modifications of these levels induced in response to changed social context (queen removal) may differ between ants from various systematic groups.

\section{CONCLUSIONS}

The main aim of this review was to demonstrate that proximate causal factors involved in the mediation of insect social behavior include cues and signals originating not only from lower levels of organization encountered in insect societies, but also from social environment of the individual. Moreover, the mode of action and the effects of administration of specific neuroactive compounds are also context-dependent and are significantly influenced by individual properties of the tested insects (age, behavioral specialization, reproductive status etc.), systematic group to which they belong, and external conditions including past and present social context.

Summary

The main aim of this review was to show that proximate causation of insect social behavior involves complex interplay of cues and signals originating from both lower and higher levels of organization encountered in insect societies. We focused our review on context- 
dependence of neuromodulation of insect social behavior by specific neuroactive compounds including several biogenic amines (octopamine, serotonin, dopamine and tyramine), and classical amino acid neurotransmitters [ $\gamma$-aminobutyric acid (GABA) and glutamate (Glu)]. We provided numerous examples of the role of these compounds in the mediation of affiliative social contacts, aggressive behavior, ontogeny of behavior (including behavioral reversion), and modifications of the reproductive status of the individual. We also discussed how brain contents of specific neuroactive compounds and the effects of their administration depend on individual properties of the tested insects, systematic group to which they belong, and external conditions defining their past and present physical and social environment.

\section{REFERENCES}

AMDAM G. V., 2011. Social context, stress, and plasticity of aging. Aging Cell 10, 18-27.

AONUMA H., WATANABE T., 2012a. Octopaminergic system in the brain controls aggressive motivation in the ant, Formica japonica. Acta Biol. Hung. 63 (Suppl. 2), 63-68.

Aonuma H., WATANABE T., 2012b. Changes in the content of brain biogenic amine associated with early colony establishment in the queen of the ant Formica japonica. Plos One 7, 1-8.

BARRON A. B., ROBINSON G. E., 2005. Selective modulation of task performance by octopamine in honey bee (Apis mellifera) division of labour. J. Comp. Physiol. A 191, 659-668.

BARRON A. B., MAlEszKA R., VANDER MEER R. K., RoBINSON G. E., 2007. Octopamine modulates honey bee dance behavior. Proc. Natl. Acad. Sci. USA 104, 1703-1707.

BEHRENDS A., SCHEINER R., 2012. Octopamine improves learning in newly emerged bees but not in old foragers. J. Exp. Biol. 215, 10761083.

BOUlay R. J., AUger E. J., LENOIR A., 1999a. Influence of octopamine on trophallactic behaviour in the ant Camponotus fellah (Hymenoptera, Formicidae). Actes Coll. Ins. Soc. 12, 127-130.

Boulay R. J., QuAgebeur M., GodzińSKa E. J., LENOIR A., 1999b. Social isolation in ants: evidence of its impact on survivorship and behavior in Camponotus fellah (Hymenoptera, Formicidae). Sociobiology 33, 111-124.

BOUlay R., HEFETZ A., SOROKER V., LENOIR A., 2000a. Camponotus fellah colony integration: worker individuality necessitates frequent hydrocarbon exchanges. Anim. Behav. 59, 1127 1133.

BOUlay R., SOROKER V., GODZińSKa E. J., HEFETZ A., LENOIR A., 2000b. Octopamine reverses the isolation-induced increase in trophallaxis in the carpenter ant Camponotus fellah. J. Exp. Biol. 203, 513-520.

Boulay R., KatzaV-Gozansky T., VANDER MEeR R. K., HeFETz A., 2003. Colony insularity through queen control on worker social motivation in ants. Proc. Biol. Sci. 270, 971-977.

Boulay R., KatzaV-Gozansky T., Hefetz A., LENOIR A., 2004. Odour convergence and tolerance between nestmates through trophallaxis and grooming in the ant Camponotus fellah (Dalla Torre). Insect. Soc. 51, 55-61.

BubaK A. N., YAEGER J. D. W., RenNeR K. J., Swallow J. G., GREene M. J., 2016. Neuromodulation of nestmate recognition decisions by pavement ants. Plos One 11, e0166417.
Cuvillier-Hot V., LENOIR A., 2006. Biogenic amine levels, reproduction and social dominance in the queenless ant Streblognathus peetersi. Naturwissenschaften 93, 149-153.

CyBUlska A., GoDZIŃSKA E. J., 1999. Trofalaksja: stary termin, nowe pytania. Wszechświat 100, 4-6.

Cybulska A., Godzińska E. J., Wagner-Ziemka A. 2000. Behaviour of dyads of ants reunited after social deprivation. Biol. Bull. Poznań 37, 119-127.

CZECHOWSKI W., 1996. Colonies of hybrids and mixed colonies; interspecific nest takeover in wood ants (Hymenoptera, Formicidae). Memor. Zool. 50, 1-116.

Dahbi A., Hefetz A., Cerda X., Lenoir A., 1999. Trophallaxis mediates uniformity of colony odor in Cataglyphis iberica ants (Hymenoptera, Formicidae). J. Insect Behav. 12, 559567.

DOBRZAŃSKA J.,1959. Studies on the division of labour in ants genus Formica. Acta Biol. Exp. 19, 57-81.

Dussutour A., Poissonnier L.- A., Buhl J., SimPSON S. J., 2016. Resistance to nutritional stress in ants: when being fat is advantageous. J. Exp. Biol. 219, 824-833.

FÉNÉRON R., DURAND J.- L., JAISSON P., 1996. Relation between behaviour and physiological maturation in a ponerine ant. Behaviour 133, 791-806.

FOREL A., 1874. Les fourmis de la Suisse. Société Helvétique des Sciences Naturelles, Zurich, Switzerland.

FriedMAN D. A., PILKo A., SKOWRONSKA-KRAWCZYK D., KRASINSKA K., PARKER J. W., HiRSH J., GORDON D. M., 2018. The role of dopamine in the collective regulation of foraging in harvester ants. iScience 8, 283-294.

GAlizia G., EISENHARDT D., GIURFA M. (Eds.) 2012. Honeybee neurobiology and behavior. A tribute to Randolf Menzel. Springer, Dordrecht.

Giraldo Y. M., PATEla E., GRONEnBERG W., TRANIELLO J. F. A., 2013. Division of labor and structural plasticity in an extrinsic serotonergic mushroom body neuron in the ant Pheidole dentata. Neuroscience Lett. 534,107-111.

Giraldo Y. M., Rusakov A., Diloreto A., KordeK A., TRANiEllo J. F. A., 2016. Age, workersite location, neuromodulators, and task performance in the ant Pheidole dentata. Behav. Ecol. Sociobiol. 70, 1441-1455.

GIURFA M., SANDOZ J. C., 2012. Invertebrate learning and memory: fifty years of olfactory conditioning of the proboscis extension response in honeybees. Learn. Memory 19, 5466.

GODZIŃSKA E. J., 1996. Etologia owadów społecznych: fakty $i$ kontrowersje. Kosmos 45, 163-178.

GODZIŃSKA E. J., 1997. Etologiczna analiza zachowania sie $i$ jego uwarunkowań przyczynowych. Kosmos 46, 181-192.

GODZIŃSKA E. J., 2006. Definicja $i$ cele poznawcze neurosocjobiologii. Kosmos 55, 137-148.

GoDZIŃSKA E. J., 2007. Owady społeczne: mity $i$ fakty. Kosmos 56, 371-381.

GODZIŃSKA E. J., 2016. Human and ant social behavior should be compared in a very careful way to draw valid parallels. Behav. Brain Sci. 39, e98.

GODZIŃSKA E. J., 2019. Etologia $i$ co dalej? Niektóre filozoficzne kwestie kształtujace badania zachowania zwierzat. Filozofia i Nauka 7, 6989. 
GORDON D. M., 1996. The organization of work in social insect colonies. Nature 380, 121-124.

HAMmeR M., 1993. An identified neuron mediates the unconditioned stimulus in associative olfactory learning in honeybees. Nature 366, 59-63.

HAMmer M., Menzel R., 1998. Multiple sites of associative odor learning as revealed by local brain microinjections of octopamine in honeybees. Learn. Memory 5, 146-156.

HARRIS J. W., WOODRING J., 1992. Effects of stress, age, season, and source colony on levels of octopamine, dopamine and serotonin in the honey bee (Apis mellifera L.) brain. J. Insect. Physiol. 38, 29-35.

Herb B. R., Wolschin F., Hansen K., ARYee M. J., LANGMEAD B., IRIZARRY R., AMDAM G. V., FEINBERG A. P., 2012. Reversible switching between epigenetic states in honeybee behavio ral subcastes. Nat. Neurosci. 15, 1371-1373.

HOOVER K. M., BUBAK A. N., LAW I. J., YAEGER J. D. W., RENner K. J., Swallow J. G., GREENE M. J., 2016. The organization of societal conflicts by pavement ants Tetramorium caespitum: an agent-based model of amine-mediated decision making. Curr. Zool. 62, 277-284.

HowARD R. W., BLOMQUisT G. J., 2005. Ecological, behavioral, and biochemical aspects of in sect hydrocarbons. Annu. Rev. Entomol. 50, 371-393.

HÖllDOBLER B., WiLson E. O., 1990. The ants. Harvard University/Belknap Press, Cambridge, MA.

HÖlLDOBLER B., WiLsON E. O., 2009. The superor ganism. The beauty, elegance and strangeness of insect societies. W. W. Norton, New York - London.

HuANG Z. -Y., Robinson G. E., 1996. Regulation of honey bee division of labor by colony age demography. Behav. Ecol. Sociobiol. 39, 147158.

Ilies I., Muscedere M. L., TRANiello J. F. A., 2015. Neuroanatomical and morphological trait clusters in the ant genus Pheidole: evidence for modularity and integration in brain structure. Brain Behav. Evol. 85, 63-76.

KAITA S., KUWAHARA M., OZAKI M., YAMAOKA R., 2004. Decreased aggressiveness of ants (Camponotus japonicus) are concerned in octopamine, and octopamine receptors. Zoological Sci. 23, 1197.

KAMHI J.F., TRANIELLO J.F.A., 2013. Biogenic amines and collective organization in a superorganism: neuromodulation of social behavior in ants. Brain, Behav. Evolut. 82, 220-236.

KamHi J. F., NUNN K., Robson S. K. A., TRANIELlo J. F. A., 2015. Polymorphism and division of labour in a socially complex ant: neuromodulation of aggression in the Australian weaver ant, Oecophylla smaragdina. Proc. R. Soc. B 282, 20150704.

Kamhi J. F., ARganda S., Moreau C. S., TranielLO J. F. A., 2017. Origins of aminergic regulation of behavior in complex insect social systems. Front. Syst. Neurosci. 11, 74

KATZAV-GOZANSKY T., BOUlAY R., VANDER MEER R., HEFETZ A., 2004. In-nest environment modulates nestmate recognition in the ant Camponotus fellah. Naturwissenschaften 91, 18690.

KoRCZYŃSKA J., SZCZUKA A., KIERUZEL M., MAJCZYŃSKI H., KHVOROSTOVA N., GODZIŃSKA E. J., 2005. Effects of the biogenic amines, dopamine, tyramine and octopamine on the behavior of the carpenter ant workers ICamponotus herculeanus (Hymenoptera: Formici- dae)] during nestmate reunion tests carried out after a period of social isolation. Sociobiology 45, 409-447.

KORCZYŃSKA J., SZCZUKA A., SYMONOWICZ B., WNUK A., Gonzalez Szwacka A., MaZurkiewicz P., STUDNICKI M., GODZIŃSKA E. J., 2014. The effects of age and past and present behavioral specialization on behavior of workers of the red wood ant Formica polyctena Först. during nestmate reunion tests. Behav. Process. 107, 24-41.

KosTOWSKI W., 1966. A note on the effects of some psychotropic drugs on the aggressive behaviour in the ant, Formica rufa. J. Pharm. Pharmacol. 18, 747-749.

KostOWSKI W., 1968. A note on the effects of some cholinergic and anticholinergic drugs on the aggressive behaviour and spontaneous electrical activity of the central nervous system in the ant, Formica rufa. J. Pharm. Pharmacol. 20, 381-384.

KostowsKI W., 1994. Zachowanie agresywne mrówek a substancje neuroprzekaźnikowe. Wszechświat 95, 115-119.

KostowskI W, TARCHALSKA B., 1972. The effects of some drugs affecting brain 5-HT on the aggressive behaviour and spontaneous electrical activity of the central nervous system of the ant, Formica rufa. Brain Res. 38, 143-149.

Kostowski W., BECK J., MEszaros J., 1966. Studies on the effect of certain neurohormones and psychotropic drugs on bioelectric activity of the central nervous system and behavior in ants (Formica rufa L.). Acta Physiol. Pol. 17, 98-110.

Kostowski W., TARChalska B., WAŃchOWICZ B., 1975a. Brain catecholamines, spontaneous bioelectrical activity and aggressive behavior in ants (Formica rufa). Pharmac. Biochem. Behav. 3, 337-342.

KOSTOWSKI W., TARCHALSKA-KRYŃSKA B., MARKOWSKA L., 1975b. Aggressive behavior and brain serotonin and catecholamines in ants (Formica rufa). Pharmac. Biochem. Behav. 3, 717-719.

KOSTOWSKI W. WYSOKOWSKI J. TARCHALSKA B., 1972. The effects of some drugs modifying brain 5-hydroxytryptamine on the aggressiveness and spontaneous bioelectrical activity of the central nervous system of the ant Formica rufa. Dissert. Pharm. Pharmacol. 24, 233.

Koyama S., Matsui S., Satoh T., Sasaki K., 2015. Octopamine and cooperation: octopamine regulates the disappearance of cooperative behaviours between genetically unrelated founding queens in the ant. Biol Lett. 11, 20150206.

LEONHARDT S. D., MENZEL F., NEHRING V., SCHMitT T., 2016. Ecology and evolution of communication in social insects. Cell 164, 1277-1287.

LENOIR A., 1979. Le comportement alimentaire et la division du travail chez la fourmi Lasius niger. Bull. Biol. Fr. Belg. 113, 79-314.

LENOIR A., 1987. Factors determining polyethism in social insects. [In:] From individual to collective behavior in social insects. PASTEELS J. M., Deneubourg J. L. (eds.), Experientia Suppl. 54, 219-240.

Lenoir A., Cuisset B., Hefetz A., 2001a. Effects of social isolation on hydrocarbon patterns and nestmate recognition in the ant Aphenogaster senilis (Hymenoptera: Formicidae). Insect. Soc. 48, 101-109.

LENOIR A., HEFETZ A., Simon T., Soroker V., 2001b. Comparative dynamics of gestalt odour formation in two ant species Camponotus fellah and Aphenogaster senilis (Hymenoptera: Formicidae). Physiol. Entomol. 26, 275-283. 
Liang Z. S., NGUyen T., MatTila H. R., RODRIGUeZ-ZAS S. L., SEELEY T. D., RoBinson G. E., 2012. Molecular determinants of scouting behavior in honey bees. Science 335, 12251228.

MAZURKIEWICZ P. J., 2019. Neurochemiczne, hormonalne $i$ spoleczne uwarunkowania ontogenezy zachowań agresywnych mrówek. Ph. D. Thesis, Faculty of Biology, University of Warsaw.

MazURKiewicz P. J., Szczepanik J., Wild A., NieLUBOWICZ M., GoDZińsKA E. J., 2015. Mrówka na każdy dzień. Wydawnictwo SCRIPT, Warszawa.

MAZURKIEWICZ P. J., Wagner-ZiemKa A., MiReCKA A., GODZIŃSKA E. J. 2016. Behaviour of intranidal and extranidal major workers of the African carpenter ant Camponotus maculatus Fabricius (Hymenoptera: Formicidae) during dyadic nestmate reunion tests. Afr. Entomol. 24, 307-320.

MCDONALD P., TOPOFF H., 1985. Social regulation of behavioral development in the ant, Novomessor albisetosus (Mayr). J. Comp. Psychol. 99, 3-14.

MENZEL R., MÜLler U., 1996. Learning and memory in honeybees: from behaviour to neural substrates. Rev. Neurosci. 19, 379-404.

MERSCH D. P., CRESPI A., KelleR L., 2013. Tracking individuals shows spatial fidelity is a key regulator of ant social organization. Science 340,1090-1093.

MoRoN D., WiTEK M., Woyciechowski M., 2008. Division of labour among workers with different life expectancy in the ant Myrmica scabrinodis. Anim. Behav. 75, 345-350.

Muscedere M. L., Traniello J. F. A., 2012. Division of labor in the hyperdiverse ant genus Pheidole is associated with distinct subcaste and age-related patterns of worker brain organization. Plos One 7: e31618.

Muscedere M. L., Johnson N., Gillis B. C., KAMHI J. F., TRANIEllo J. F. A., 2012. Serotonin modulates worker responsiveness to trail pheromone in the ant Pheidole dentata. J. Comp. Physiol. A 198, 219-227.

MÜNCH D., AMDAM G. V., Wolschin F., 2008. Ageing in a eusocial insect: molecular and physiological characteristics of life span plasticity in the honey bee. Funct. Ecol. 22, 407421 .

Nielsen J., Boomsma J. J., Oldham N. J., PeTERSEN H. C., MORGAN E. D., 1999. Colonylevel and season-specific variation in cuticular hydrocarbon profiles of individual workers in the ant Formica truncorum. Insect. Soc. 46, 58-65.

OHKAWARA K., AONuma H., 2016. Changes in the levels of biogenic amines associated with aggressive behavior of queen in the social parasite ant Vollenhovia nipponica. Insect. Soc. 63, 257-264.

Отто D., 1958. Über die Arbeitsteilung im Staate Formica rufa rufo-pratensis minor Gössw. und ihre verhaltensphysiologischen Grundlagen: ein Beitrag zur Biologie der Roten Waldameise. Wiss. Abh. Dt. Akad. Landw. Wiss. Berlin 30, 1-169.

OZAKI M., KUWAHARA M., WADA-KATSUMATA A., YAMAOKA R., 2004. Octopamine increases aggression threshold in the ant, Camponotus japonicus. Comp. Biochem. Physiol. B 139, 781.

PAGE R. E., Amdam G. V., 2007. The making of a social insect: developmental architectures of social design. BioEssays 29, 334-343.
PAGE R. E., SCHEINER R., ERBER J., AMDAM G. V., 2006. The development and evolution of division of labor and foraging specialization in a social insect (Apis mellifera L.). Curr. Top. Dev. Biol. 74, 253-286.

Poole T. B., 1985. Social behaviour in mammals. Springer, Boston, MA.

PunZO F., WILliAMS D. F., 1994. Free amino acids and biogenic amines in the brain of the carpenter ant, Camponotus floridanus Buckley (Hymenoptera, Formicidae). Comp. Biochem. Physiol. C 107, 387-392.

RoBINSON E. J. H., 2009. Physiology as a castedefining feature. Insect. Soc. 56, 1-6.

RoBINSON G. E. 1992. Regulation of division of labor in insect societies. Annu. Rev. Entomol. 37, 637-665.

RoBinson G. E., FAHRBACH S. E., Winston M. L., 1997. Insect societies and the molecular biology of social behavior. BioEssays 19, 10991108.

Robinson G. E., Grozinger C. M., Whitfield W., PAGE R. E. JR., STRAMBI C., STRAMBI A., 1992. Colony integration in honey bees: mechanisms of behavioral reversion. Ethology 90, 336-348.

Robinson G. E., Heuser L. M., LeConte Y., LENQUETTE F., HOLLINGWORTH R. M., 1999. Neurochemicals aid bee nestmate recognition. Nature 399, 534-535.

ROEDER T., 2005. Tyramine and octopamine: ruling behavior and metabolism. Annu. Rev. Entomol. 50, 447-477.

Roeder T., SEIfert M., KäHler C., Gewecke M., 2003. Tyramine and octopamine: antagonistic modulators of behavior and metabolism. Arch. Ins. Biochem. Physiol. 54, 1-13.

RöscH G. A., 1930. Untersuchungen über die Arbeitsteilung im Bienenstaat II. Die Tätigkeiten der Arbeitsbienen unter experimentell veränderten Bedingungen. Z. Vergl. Physiol. $12,1-71$.

SChEINER R., BAUMANN A., Blenau W., 2006. Aminergic control and modulation of honeybee behavior. Curr. Neuropharmacol. 4, 259-276.

SCHEINER R.,TOTEVA A., REIM T., SøVIK E., BARRON A. B., 2014. Differences in the phototaxis of pollen and nectar foraging honey bees are related to their octopamine brain titers. Front. Physiol. 5, 116.

Schulz D. J., RoBinson G. E., 1999. Biogenic amines and division of labor in honey bee colonies: behaviorally related changes in the antennal lobes and age-related changes in the mushroom bodies. J. Comp. Physiol. A 184, 481-488.

SchulZ D. J., RoBinson G. E. 2001. Octopamine influences division of labor in honey bee colonies. J. Comp. Physiol. A 187, 53-61.

SCHULZ D. J., BARRON A. B., ROBINSON G. E., 2002a. A role for octopamine in honey bee division of labor. Brain Behav. Evol. 60, 350359.

Schulz D. J., Sullivan J. P., Robinson G. E., $2002 \mathrm{~b}$. Juvenile hormone and octopamine in the regulation of division of labor in honey bee colonies. Horm. Behav. 42, 222-231.

Schulz D. J., EleKonich M. M., Robinson G. E., 2003. Biogenic amines in the antennal lobes and the initiation and maintenance of foraging behavior in honey bees. J. Neurobiol. 54, 406-416.

SeID M. A., TRANiello J. F. A., 2005. Age-related changes in biogenic amines in individual brains of the ant Pheidole dentata. Naturwissenschaften 92, 198-201. 
SEID M. A., GoOdE K., LI C., TRAniello J. F A., 2008. Age and subcaste related patterns of serotonergic immunoreactivity in the optic lobes of the ant Pheidole dentata. Dev. Neurobiol. 68, 1325-1333.

Sledge M. F., Boscaro F., Turillazzi S., 2001. Cuticular hydrocarbons and reproductive status in the social wasp Polistes dominulus. Behav. Ecol. Sociobiol. 49, 401-409.

SORENSEN A. A., BUSCH T. M., Vinson S. B. 1984. Behavioral flexibility of temporal subcastes in the fire ant, Solenopsis invicta in response to food. Psyche 91, 319-331.

SOROKER V., VIENNE C., HEFETZ A., NOWBAHARI E., 1994. The postpharyngeal gland as a "Gestalt" organ for nestmate recognition in the ant Cataglyphis niger. Naturwissenschaften 81 , 510-513.

SPIVAK M., MASTERman R., Ross R., MEsce K. A. 2003. Hygienic behavior in the honey bee (Apis mellifera L.) and the modulatory role of octopamine. J. Neurobiol. 55, 341-354.

ŠUSTKOVÁ-FIŠEROVÁ M., VÁVROVÁ J., KRŠIAK M. 2009. Brain levels of GABA, glutamate and aspartate in sociable, aggressive and timid mice: an in vivo microdialysis study. Neuroendocrinology Lett. 30, 79-84.

SYMONOWICZ B., KIERUZEL M., SZCZUKA A., KORCZYŃSKA J., WNUK A., MAZURKIEWICZ P. J., CHILIŃSKI M., GodZIŃsKA E. J., 2015. Behavioral reversion and dark-light choice behavior in workers of the red wood ant Formica polyctena. J. Insect Behav. 28, 245-256.

SZCZUKA A., 1996. Elastyczność behawioralna mrówek. Kosmos 45, 433-442.

SZCZUKA A., GODZIŃSKA E. J., 1997. The effect of past and present group size on responses to prey in the ant Formica polyctena Först. Acta Neurobiol. Exp. 57, 135-150.

SZCZUKA A., GODZIŃSKA E. J., 2000. Group size: an important factor controlling the expression of predatory behaviour in workers of the wood ant Formica polyctena Först. Biol Bull. Poznań 37, 139-152.

SzCZUKA A., GoDZIŃSKA E. J., 2004a. The role of group size in the control of expression of predatory behaviour in workers of the red wood ant Formica polyctena (Hymenoptera: Formicidae). Sociobiology 43, 295-325.

SZCZUKA A., GODZINSSKA E. J., 2004b. The effect of gradual increase of group size on the expression of predatory behaviour in workers of the red wood ant Formica polyctena (Hymenoptera: Formicidae). Sociobiology 43, 327-349.

SZCZUKA A., GODZIŃSKA E. J., 2008. Effect of chronic oral administration of octopamine on the expression of predatory behavior in small groups of workers of the red wood ant Formica polyctena (Hymenoptera: Formicidae). Sociobiology 52, 703-728.

SZCZUKA A., KORCZYŃSKA J., WNUK A., SYMONOWICZ B., GONZALEZ SZWACKA A., MAZURKIEWICZ P., Kostowski W., Godzinska E. J., 2013. The effects of serotonin, dopamine, octopamine and tyramine on behavior of workers of the ant Formica polyctena during dyadic aggression tests. Acta Neurobiol. Exp. 73, 495-520.

TARCHALSKA B., KOSTOWSKI W., MARKOWSKA L., MARKIEWICZ L., 1975. On the role of serotonin in aggressive behavior of ants genus Formica. Pol. J. Pharmacol. 27 (Suppl), 237-239.
Tотн A. L., RoBinson G. E., 2005. Worker nutrition and division of labour in honeybees. Anim. Behav. 69, 427-435.

VANDER MEer R. K., PREston C. A., Hefetz A., 2008. Queen regulates biogenic amine level and nestmate recognition in workers of the fire ant, Solenopsis invicta. Naturwissenschaften 95, 1155-1158.

WADA-KATSUMATA A., YAMAOKA R., AONUMA H., 2011. Social interactions influence dopamine and octopamine homeostasis in the brain of the ant Formica japonica. J. Exp. Biol. 214, 1707-1715.

Wagener-Hulme C., Schulz D. J., Kuehn J. C., RoBINSON G. E., 1999. Biogenic amines and division of labor in honey bee colonies. J. Comp. Physiol. A 184, 471-479.

WAGNER D., TISSOT M., GORDON D., 2001. Taskrelated environment alters the cuticular hy drocarbon composition of harvester ants. J. Chem. Ecol. 27, 1805-1819.

WAGNER-ZIEMKA A., GONZALEZ SZWACKA A., KORCZYŃSKA J., KIERUZEL M., FIAŁKOWSKA B., GODZIŃSKA E. J., 2008. Comparison of the behavior of nurses and foragers of the carpenter ant, Camponotus melanocnemis, during dyadic nestmate reunion tests carried out after a period of social isolation (Hymenoptera: Formicidae). Sociobiology 52, 2-36.

Whitfield C. W., CZIKo A. M., Robinson G. E., 2003. Gene expression profiles in the brain predict behavior in individual honey bees. Science 302, 296-299.

Wilson E. O., 1971. The insect societies. Harvard University/Belknap Press, Cambridge, MA.

Wilson E. O., HöllDOBLER B., 1988. Dense heterarchies and mass communication as the basis of organization in ant colonies. TREE 3, 6568.

WNUK A., 2008. Bezkręgowce jako organizmy modelowe: alternatywa dla kregowców. Prace i Materiały Zootechniczne 66, 166-168.

WNUK A., 2012. Neurochemiczne $i$ spoleczne uwarunkowania zachowañ agresywnych mrówek. Ph. D. Thesis, Nencki Institute of Experimental Biology PAS, Warsaw.

WNUK A., 2013. Neurobiologiczne korelaty rozwoju behawioralnego robotnic owadów społecznych. Kosmos 62, 513-523.

WNUK A., GoDZIŃSKA E. J., 2006. Wpływ izolacji społecznej na fizjologie $i$ zachowanie sie mrówek. Kosmos 55, 177-196.

WNUK A., WiATER M., GODZIŃSKA E. J., 2011. Ef fect of past and present behavioural specialization on brain levels of biogenic amines in workers of the red wood ant Formica polyctena. Physiol. Entomol. 36, 54-61.

WNUK A., KOSTOWSKI W., KORCZYŃSKA J., SZCZUKA A., SYMONOWICZ B., BIEŃKOWSKI P., MIERZEJEWSKI P., GODZIŃSKA E. J., 2014. Brain GABA and glutamate levels in workers of two ant species (Hymenoptera: Formicidae): interspecific differences and effects of queen presence/absence. Insect Sci. 21, 647-658.

WoYcIECHOWSKI M., MORON D., 2009. Life expectancy and onset of foraging in the honeybee. Insect. Soc. 56,193-201.

YAKOVLEV I. K., 2018. Effects of octopamine on aggressive behavior in red wood ants. Neurosci. Behav. Physiol. 48, 279-288. 
KOSMOS Vol. 68, 4, 575-589, 2019

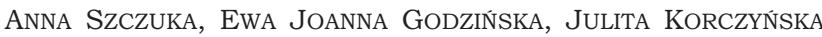

Pracownia Etologii, Instytut Biologii Doświadczalnej im. M. Nenckiego PAN, Pasteura 3, 02-093 Warszawa, E-mail: e.godzinska@nencki.edu.pl

\title{
CZYNNIKI STERUJĄE ZACHOWANIAMI SPOŁECZNYMI MRÓWEK: WSPÓŁODDZIAŁYWANIE NEUROMODULACJI I KONTEKSTU SPOŁECZNEGO
}

\section{Streszczenie}

Główym celem tego przeglądu było ukazanie, w jaki sposób bezpośrednie (proksymatywne) uwarunkowania przyczynowe zachowań społecznych owadów opieraja się na złożonym współoddziaływaniu bodźców i sygnałów pochodzących zarówno $z$ niższych, jak i z wyższych poziomów organizacji występujących w społeczeństwach owadów. Szczególny nacisk położyliśmy w nim na zależność od kontekstu cechującą neuromodulację zachowań społecznych owadów przez specyficzne zwiazki neuroaktywne, takie jak aminy biogenne (oktopamina, serotonina, dopamina i tyramina) oraz klasyczne neuroprzekaźniki aminokwasowe [kwas $\gamma$-aminomasłowy (GABA) i glutaminian (Glu)]. Przedstawiliśmy liczne przykłady roli tych związkow w sterowaniu afiliacyjnymi kontaktami społecznymi, zachowaniami agresywnymi, ontogenezą zachowań (łącznie $z$ rewersją behawioralną) i modyfikacjami statusu rozrodczego osobnika. Przedyskutowaliśmy też, w jaki sposób zawartość specyficznych związków neuroaktywnych w mózgu oraz skutki ich podawania zależą od indywidualnych cech badanych owadów, grupy systematycznej, do której należą, oraz warunków zewnętrznych definiujących ich przeszłe i obecne środowisko fizyczne i społeczne.

Słowa kluczowe: kontekst spłeczny, mrówki, neuromodulacja, owady społeczne, zachowania społeczne 